AR-RIHLAH: JURNAL KEUANGAN DAN PERBANKAN SYARIAH

Vol. 01, No. 01 Maret 2021, hlm. 46-54

Available at https://jurnal.unsur.ac.id/ar-rihlah/index

\title{
PENGARUH PEMBIAYAAN IJARAH DAN PEMBIAYAAN QARDH TERHADAP TINGKAT LABA BERSIH DI BANK BRI SYARIAH
}

\author{
Eneng Elyana ${ }^{1}$, Jalaluddin ${ }^{2}$, Nuraeni ${ }^{3}$ \\ 1,2,3Perbankan Syariah, STIBANKS Al-Masoem \\ enengelyana2016ps@gmail.com \\ \begin{tabular}{l|l|l} 
Masuk: Januari 2021 & Penerimaan: Februari 2021 & Publikasi: Maret 2021
\end{tabular}
}

\begin{abstract}
ABSTRAK
Berdasarkan hasil observasi bahwa yang melatarbelakangi penelitian ini yaitu terjadinya fluktuatif pada laporan keuangan pembiayaan ijarah dan qardh yang akan berdampak terhadap laba bersih Bank BRI Syariah. Penelitian ini bertujuan untuk mengetahui bagaimana pengaruh pembiayaan ijarah dan pembiayaan qardh terhadap laba bersih baik secara parsial maupun simultan. Objek penelitian yaitu menggunakan laporan keuangan Bank BRI Syariah. Jenis penelitian yaitu kuantitatif asosiatif dengan jenis data sekunder. Adapun populasi dan sampel yaitu laporan keuangan triwulanan tentang pembiayaan ijarah dan pembiayaan qardh periode 2015-2019. Teknik pengumpulan data berupa observasi, wawancara, studi pustaka, dan dokumentasi. Hasil Penelitian menunjukan bahwa tidak terdapat pengaruh signifikan antara pembiayaan ijarah terhadap laba bersih dimana $t_{\text {hitung }}$ sebesar $-0,1482<$ $t_{\text {tabel }}$ sebesar 2.109, tidak terdapat pengaruh signifikan antara pembiayaan qardh terhadap laba bersih dimana nilai $t_{\text {hitung }}$ sebesar $-0,991<$ $t_{\text {tabel }}$ sebesar 2.109 , serta tidak berpengaruh signifikan pembiayaan ijarah dan qardh secara simultan terhadap laba bersih dimana nilai $\mathrm{F}_{\text {hitung }} 0,474<$ $\mathrm{F}_{\text {tabel }} 3,59$.
\end{abstract}

Kata kunci: Pembiayaan Ijarah; Pembiayaan Qardh; dan Laba Bersih.

\begin{abstract}
Based on the results of the observation that the background of this research is the fluctuation in the financial statements of ijarah and qardh financing which will have an impact on the net profit of BRI Syariah Bank. This study aims to determine how the effect of ijarah financing and qardh financing on net income either partially or simultaneously. The object of research is to use the financial statements of Bank BRI Syariah. This type of research is associative quantitative with secondary data types. The population and sample are quarterly financial reports on ijarah financing and qardh financing for the 2015-2019 period. Data collection techniques in the form of observation, interviews, literature study, and documentation. The results showed that there was no significant influence between ijarah financing on net income where tcount was $-0.1482<$ ttable was 2.109, there was no significant effect between qardh financing on net income where the tcount value was -0.991<ttable was 2.109, and had no effect. significant ijarah and qardh financing simultaneously on net income where the value of Fcount $0.474<$ Ftable 3.59.
\end{abstract}

Keywords: Ijarah Financing; Qardh Financing; and Net Income. 


\section{A. PENDAHULUAN}

Pada zaman sekarang banyak lembaga keuangan yang mampu memenuhi berbagai kebutuhan masyarakat, salah satunya adalah perbankan, dalam dunia perbankan sudah terdapat produk-produk yang mendukung sistem operasionalnya terutama untuk penyaluran dana kepada masyarakat dimana setiap produk tersebut memiliki kekurangan dan kelebihan baik untuk nasabah maupun bank itu sendiri (U. A. and R. J. Husaeni, 2020). Selain perbankan konvensional, kini di Indonesia sudah terdapat bank yang berbasis syariah sehingga masyarakat tidak perlu khawatir dengan sistem riba, meskipun mayoritas masyarakat kurang begitu memahami apa itu perbankan syariah namun seiring berjalannya waktu masyarakat banyak yang menjadi nasabah bank syariah (U. A. Husaeni, 2017).

Bank yang berbasis syariah diantaranya bank BRI Syariah. Bank BRI Syariah merupakan salah satu dari tiga Bank Syariah terbesar di Indonesia. Selain itu bank BRI Syariah berfokus pada segmen menengah kebawah, Bank BRI Syariah menargetkan diri menjadi bank terkemuka dengan berbagai macam produk dan layanan yang optimal (Akhmad, 2016).

Adapun produk atau jasa yang ditawarkan Bank BRI Syariah diantaranya pembiayaan. Pembiayaan yaitu berupa penyaluran dana baik itu dalam bentuk barang atau jasa yang diberikan bank untuk nasabahnya dengan kebijakan tertentu dengan menggunakan akad yang sesuai dengan produk yang dipilih yang dilakukan diawal perjanjian (U. A. Husaeni, 2016). Beberapa pembiayaan yang ada di Bank Syariah salah satunya yaitu pembiayaan Ijarah dan Qardh.

Transaksi Ijaroh merupakan salah satu bentuk kegiatan muamalah yang banyak dilakukan manusia untuk memenuhi kebutuhan hidup. Definisi ijaroh menurut para fukoha dapat dilihat dalam (Zuhaily, 1989) ijaroh adalah akad atau transaksi terhadap manfaat dengan imbalan. Sedangkan pembiayaan Qardh menurut Syafii (2001) adalah meminjamkan harta kepada orang lain yang dapat dikembalikan kapan saja tanpa adanya tambahan dari jumlah yang dipinjamkan atau dengan tidak mengharapkan imbalan.

Berdasarkan teori diatas bahwa secara singkat pembiayaan Qardh lebih mudah dibandingkan dengan pembiayaan Ijarah yang harus membayar upah sewa. 
namun pada kenyataan menunjukan bahwa nasabah lebih banyak menggunakan pembiayaan dengan akad ijarah. Salah satu faktor penyebabnya adalah nasabah beranggapan jika pembiayaan ijarah lebih memenuhi kebutuhan sehari-harinya meskipun harus membayar upah sewa kepada bank dibandingkan dengan qardh yang hanya digunakan pada saat kebutuhan mendadak saja sehingga pada pembiayaan Ijarah lebih mengalami peningkatan berbeda dengan pembiayaan Qardh. Berikut ini adalah laporan perkembangan pembiayaan Ijarah, Qardh dan laba bersih Bank BRI Syariah periode 2015-2019.

Tabel 1. Perkembangan Pembiayaan Ijarah, Qardh dan Laba bersih Bank BRI Syariah (Dalam Jutaan Rupiah)

\begin{tabular}{|c|c|c|c|c|c|c|c|}
\hline $\begin{array}{l}\text { Ta- } \\
\text { hun }\end{array}$ & $\begin{array}{l}\text { Triw } \\
\text { ulan }\end{array}$ & $\begin{array}{c}\text { Pembiayaan } \\
\text { Qardh }\end{array}$ & $(\%)$ & $\begin{array}{c}\text { Pembiayaan } \\
\text { Ijarah }\end{array}$ & $(\%)$ & $\begin{array}{c}\text { Laba } \\
\text { Bersih }\end{array}$ & $(\%)$ \\
\hline \multirow{4}{*}{2015} & I & 398.874 & & 214.410 & & 122.637 & - \\
\hline & II & 459.115 & $15,10 \%$ & 216.446 & $0,9 \%$ & 93.115 & $\begin{array}{c}(24,07 \% \\
)\end{array}$ \\
\hline & III & 514.965 & $12,2 \%$ & 213.867 & $\begin{array}{c}(1,28 \% \\
)\end{array}$ & 60.152 & $\begin{array}{c}(35,40 \% \\
)\end{array}$ \\
\hline & $1 \mathrm{~V}$ & 546.823 & $6,18 \%$ & 213.686 & $\mathbf{0 , 0 8 \%}$ & 25.292 & $95,20 \%$ \\
\hline \multirow{4}{*}{2016} & I & 295.388 & $(45,9 \%)$ & 356.320 & $67,6 \%$ & 170.209 & $44,95 \%$ \\
\hline & II & 330.163 & $11,77 \%$ & 174.901 & $\begin{array}{c}(51,1 \% \\
)\end{array}$ & 129.164 & $\begin{array}{c}(24,11 \% \\
)\end{array}$ \\
\hline & III & 347.290 & $5,19 \%$ & 214.009 & $22,3 \%$ & 101.396 & $\begin{array}{c}(30,10 \% \\
)\end{array}$ \\
\hline & IV & 345.622 & $(0,48 \%)$ & 214.581 & $0,26 \%$ & 42.951 & $\begin{array}{c}(52,42 \% \\
)\end{array}$ \\
\hline \multirow{4}{*}{2017} & I & 538.243 & $(55,7 \%)$ & 1.289 .350 & $501,1 \%$ & 101.091 & $135.3 \%$ \\
\hline & II & 223.257 & $(58,5 \%)$ & 967.664 & $\begin{array}{c}(24,9 \% \\
) \\
\end{array}$ & 127.299 & $25,92 \%$ \\
\hline & III & 238.349 & $6,75 \%$ & 780.011 & $\begin{array}{c}(19.3 \% \\
)\end{array}$ & 72.657 & $\begin{array}{c}(39,78 \% \\
) \\
\end{array}$ \\
\hline & IV & 277.352 & $16,36 \%$ & 559.300 & $\begin{array}{c}(28,2 \% \\
)\end{array}$ & 33.177 & $\begin{array}{c}(56,72 \% \\
)\end{array}$ \\
\hline \multirow{4}{*}{2018} & I & 367.004 & $32,3 \%$ & 2.101 .561 & $275.7 \%$ & 106.600 & $221,3 \%$ \\
\hline & II & 460.227 & $25,4 \%$ & 1.982.335 & $\begin{array}{c}(5,67 \% \\
)\end{array}$ & 151.148 & $41,7 \%$ \\
\hline & III & 465.618 & $1,17 \%$ & 1.830.063 & $\begin{array}{c}(25,0 \% \\
) \\
\end{array}$ & 120.157 & $\begin{array}{c}(20,50 \% \\
) \\
\end{array}$ \\
\hline & IV & 445.486 & $(4,32 \%)$ & 1.673 .051 & $12,6 \%$ & 54.381 & $\begin{array}{c}(54,74 \% \\
)\end{array}$ \\
\hline \multirow{4}{*}{2019} & I & 406.654 & $(3,7 \%)$ & 2.256 .008 & $35,4 \%$ & 72.561 & $36,105 \%$ \\
\hline & II & 439.022 & $2,43 \%$ & 2.291 .552 & $1,12 \%$ & 56.457 & $\begin{array}{c}(23,72 \% \\
)\end{array}$ \\
\hline & III & 428.564 & $(7,37 \%)$ & 2.256 .995 & $\begin{array}{c}(1,55 \% \\
) \\
\end{array}$ & 53.541 & $\begin{array}{c}(37,02 \% \\
)\end{array}$ \\
\hline & IV & 408.360 & $\mathbf{0 , 4 0 \%}$ & 2.172 .354 & $(3,7 \%)$ & 30.057 & $\begin{array}{c}(15,45 \% \\
)\end{array}$ \\
\hline
\end{tabular}

Sumber : BRI Syariah 
Berdasarkan tabel diatas dapat lihat bahwa terjadinya fluktuatif antara pembiayaan qardh dari yang terendah $-58,5 \%$ hingga yang tertinggi $16,36 \%$ dan pembiayaan ijarah dari yang terendah $-51,1 \%$ hingga yang tertinggi $501,1 \%$, sehingga menyebabkan fluktuatifnya nilai laba bersih dari yang terendah $-56,72 \%$ hingga yang tertinggi $135,3 \%$.

Sebagaimana penelitian sebelumnya, menurut Syarah Nabilah (2015) dengan judul pengaruh pinjaman qardh dan pendapatan ijarah terhadap laba bersih pada PT. Bank Syariah Mandiri cabang Bandung dengan hasil bahwa pinjaman qardh tidak berpengaruh terhadap laba bersih dan pendapatan ijarah berpengaruh terhadap laba bersih. Penelitian menurut Silfia Permata Sari (2018), dengan judul pengaruh pembiayaan ijarah dan qardh terhadap tingkat laba bersih pada Bank Umum Syariah di Indonesia Periode Tahun 2014-2017, dengan hasil bahwa pembiayaan qardh tidak berpengaruh terhadap laba bersih dan pembiayaan ijarah berpengaruh terhadap laba bersih. Tujuan penelitian ini adalah untuk mengetahui seberapa besar pengaruh pembiayaan qardh dan pembiayaan ijarah baik secara parsial maupun simultan terhadap laba bersih.

\section{B. METODE PENELITIAN}

Objek penelitian ini adalah laporan keuangan Bank BRI Syariah KCP Soreang. Jenis penelitian yaitu penelitian kuantitatif asosiatif dengan menggunakan data sekunder. Populasi dalam penelitian ini adalah laporan keuangan triwulanan dari bank BRI Syariah. Menurut Sekaran (2003) Populasi adalah keseluruhan sekelompok orang, kejadian yang akan diteliti secara meluas sehingga layak untuk diteliti, sedangkan sampel adalah sebagian dari kumpulan populasi yang mewakili seluruh populasi. Sedangkan sampel yang digunakan adalah laporan keuangan tentang Pembiayaan Ijarah dan Qardh Periode 2015-2019 yaitu diambil dari data triwulanan lima tahun terakhir. Adapun pengertian sampel menurut Fatoni (2006) Sampel artinya contoh, contoh yang digunakan sebagai objek penelitian yang nantinya akan diteliti.Teknik penguimpulan data yang dilakukan oleh peneliti yaitu sebagai berikut:

1. Observasi; sebelum melakukan penelitian penulis melakukan observasi terlebih dahulu untuk mengetahui situasi keadaan Bank BRI Syariah KCP Soreang yang akan diteliti sehingga penulis mampu menyusun rencana 
dalam penelitian yang akan dilakukan. Adapun pengertian observasi. "Observasi adalah metode pengumpulan data yang banyak dilakukan dalam desain eksperimentasi (laboratorium dan lapangan) dan studi kualitatif (Abdillah, 2018).

2. Wawancara; untuk memperoleh data yang dibutuhkan penulis maka penulis melakukan teknik wawancara dengan pimpinan bank BRI Syariah KCP Soreang yang bernama bapak Okeu. Menurut Fatoni (2006) Wawancara adalah teknik pengumpulan data dengan cara tanya jawab berupa lisan antara dua orang atau lebih dimana pertanyaan diberikan oleh pihak yang mewawancarai dan jawaban dari pihak yang diwawancarai.

3. Dokumentasi; pada Penelitian ini dokumentasi yang digunakan yaitu laporan keuangan triwulanan pada bank BRI Syariah yang dipublikasikan di situs resmi bank Indonesia. Menurut Widodo (2017) Dokumentasi merupakan kegiatan pengumpulan data yang dilakukan melalui pencarian dokumen atau data yang berupa bukti yang ada kaitannya dengan aspekaspek yang diketahui.

4. Studi Pustaka; untuk memperoleh laporan dari hasil penelitian penulis mencari referensi dari buku-buku, serta mempelajari jurnal penelitian sebelumnya yang berkaitan dengan judul untuk dijadikan bahan penulisan laporan penelitian. Menurut Widodo (2017) Studi pustaka adalah kegiatan mempelajari, mendalami serta mencari referensi yang dapat dijadikan bahan penulisan laporan, dan mengutip teori-teori atau konsep-konsep atau karya tulis lainnya yang berkaitan dengan variabel judul penelitian.

Analisis data yang digunakan adalah analisis korelasi berganda, analisis regresi berganda, analisis koefisien determinasi, uji t dan uji F.

\section{HASIL DAN PEMBAHASAN}

1. Pengaruh Pengaruh Pembiayaan Ijarah terhadap Tingkat Laba bersih di Bank BRI Syariah

Secara parsial hasil uji t dengan menggunakan IBM SPSS Statistic 23 dapat dilihat pada tabel 2 . 
Tabel 2. Uji t

Coefficients $^{\mathrm{a}}$

\begin{tabular}{|c|c|c|c|c|c|}
\hline \multirow[b]{2}{*}{ Model } & \multicolumn{2}{|c|}{$\begin{array}{c}\text { Unstandardized } \\
\text { Coefficients }\end{array}$} & \multirow{2}{*}{$\begin{array}{c}\text { Standardized } \\
\text { Coefficients } \\
\text { Beta }\end{array}$} & \multirow[b]{2}{*}{$\mathrm{T}$} & \multirow[b]{2}{*}{ Sig. } \\
\hline & B & Std. Error & & & \\
\hline (Constant) & 90.362 & 12.846 & & 7.034 & .000 \\
\hline Ijarah & $-4.659 \mathrm{E}-6$ & .000 & -.114 & -.489 & .631 \\
\hline
\end{tabular}

a. Dependent Variable: Laba Bersih

Sumber : Hasil penelitian

Berdasarkan tabel diatas dapat diketahui bahwa nilai $t_{\text {hitung }}$ sebesar -0,489 $<$ nilai $t_{\text {tabel }}$ sebesar 2.109. dan nilai sig 0,631>0,05 maka, $\mathrm{H}_{0}$ diterima $\mathrm{H}_{1}$ ditolak,artinya pembiayaan iijarah tidak berpengaruh signifikan terhadap tingkat laba bersih.

\section{Pengaruh Pembiayaan Qardh terhadap Tingkat Laba bersih di Bank}

\section{BRI Syariah}

Secara parsial hasil uji t dengan menggunakan IBM SPSS Statistic 23 dapat dilihat pada tabel 3 .

Tabel 3. Uji t Qardh

Coefficients $^{\mathbf{a}}$

\begin{tabular}{|c|c|c|c|c|c|}
\hline \multirow[b]{2}{*}{ Model } & \multicolumn{2}{|c|}{ Unstandardized Coefficients } & $\begin{array}{l}\text { Standardized } \\
\text { Coefficients }\end{array}$ & \multirow[b]{2}{*}{$\mathrm{T}$} & \multirow[b]{2}{*}{ Sig. } \\
\hline & $\mathrm{B}$ & Std. Error & Beta & & \\
\hline (Constant) & 127.054 & 42.305 & & 3.003 & .008 \\
\hline Qardh & -.103 & .104 & -.227 & -.991 & .335 \\
\hline
\end{tabular}

a. Dependent Variable: Laba Bersih

Sumber : Hasil Penelitian

Berdasarkan tabel diatas dapat dilihat bahwa nilai $t_{\text {hitung }}$ sebesar -0.991<

$t_{\text {tabel }} 2.109$ dan nilai sig sebesar 0,335>0,05 maka $\mathrm{H}_{0}$ diterima dan $\mathrm{H}_{1}$ ditolak artinya pembiayaan qardh tidak berpengaruh signifikan terhadap laba bersih.

\section{Pengaruh Ijarah dan Pembiayaan Qardh secara simultan terhadap Laba Bersih di Bank BRI Syariah}

Untuk mengetahui pengaruh ijarah dan qardh secara simultan terhadap laba bersih maka digunakan pengujian analisis korelasi berganda, analisis regresi 
berganda, analisis koefisien determinasi, dan uji $\mathrm{F}$ yang akan ditampilkan pada tabel 4,5,6, dan 7 .

Tabel 4. Analisis Korelasi Berganda

Model Summary

\begin{tabular}{|c|c|c|c|c|c|c|c|c|c|}
\hline \multirow[b]{2}{*}{ Model } & \multirow[b]{2}{*}{$\mathrm{R}$} & \multirow[b]{2}{*}{$\begin{array}{c}\mathrm{R} \\
\text { Square } \\
\end{array}$} & \multirow[b]{2}{*}{$\begin{array}{l}\text { Adjusted R } \\
\text { Square }\end{array}$} & \multirow{2}{*}{$\begin{array}{l}\text { Std. Error } \\
\text { of the } \\
\text { Estimate }\end{array}$} & \multicolumn{5}{|c|}{ Change Statistics } \\
\hline & & & & & $\begin{array}{l}\text { R Square } \\
\text { Change }\end{array}$ & \begin{tabular}{c|}
$\mathrm{F}$ \\
Change \\
\end{tabular} & df1 & $\mathrm{df} 2$ & $\begin{array}{c}\text { Sig. F } \\
\text { Change }\end{array}$ \\
\hline 1 & $\begin{array}{r}.230 \\
a\end{array}$ & .053 & -.059 & 43.372 & .053 & .474 & 2 & 17 & .630 \\
\hline
\end{tabular}

a. Predictors: (Constant), Ijarah, Qardh

b. Dependent Variable: Laba Bersih

Sumber : Hasil Penelitian

Berdasrkan tabel diatas dapat diketahui bahwa nilai $\mathrm{R}$ sebesar 0,230 artinya pembiayaan ijarah dan pembiayaan qardh memiliki hubungan rendah terhadap Laba bersih.

Tabel 5. Analisis Regresi Berganda Coefficients $^{a}$

\begin{tabular}{|c|c|c|c|c|c|c|}
\hline \multirow{2}{*}{\multicolumn{2}{|c|}{ Model }} & \multicolumn{2}{|c|}{ Unstandardized Coefficients } & \multirow{2}{*}{$\begin{array}{c}\begin{array}{c}\text { Standardized } \\
\text { Coefficients }\end{array} \\
\text { Beta }\end{array}$} & \multirow[b]{2}{*}{6} & \multirow[b]{2}{*}{ Sig. } \\
\hline & & $B$ & Std. Error & & & \\
\hline \multirow[t]{3}{*}{1} & $\begin{array}{l}\text { (Consta } \\
\text { nt) }\end{array}$ & & 44.129 & & 2.855 & 011 \\
\hline & ljarah & $-1.479 \mathrm{E}-6$ & .000 & -.036 & -.143 & .888 \\
\hline & Qardh & -.097 & .115 & -.214 & -.845 & .410 \\
\hline
\end{tabular}

a. Dependent Variable: Laba Bersih

Sumber : Hasil Penelitian

Berdasarkan hasil tabel diatas terdapat persamaan sebagai berikut :

$\mathrm{Y}=125.994-\left(-1.479 \mathrm{X}_{1}\right)+\left(-0,097 \mathrm{X}_{2}\right)+\mathrm{e}$

Keterangan :

1. Nilai konstanta, artinya jika nilai semua variabel bebas bernilai 0 (nol) maka nilai dari laba bersih sebesar 125.994

2. Nilai koefisien ijarah sebesar -1.479 , artinya jika pembiayaan ijarah mengalami penurunan satu satuan maka laba bersih mengalami pengurangan sebesar -1.479.

3. Nilai koefisien qardh sebesar -0,097, artinya jika pembiayaan qardh mengalami penurunan satu satuan maka laba bersih akan mengalami pengurangan sebesar 0,097 . 
Tabel 6. Analisis Koefisien Determinasi

Model Summaryb

\begin{tabular}{|c|c|c|c|c|c|c|c|c|c|}
\hline \multirow[b]{2}{*}{$\begin{array}{l}\text { Mod } \\
\text { el }\end{array}$} & \multirow[b]{2}{*}{$\mathrm{R}$} & \multirow{2}{*}{$\begin{array}{l}\mathrm{R} \\
\text { Squ } \\
\text { are }\end{array}$} & \multirow[b]{2}{*}{$\begin{array}{c}\text { Adjusted R } \\
\text { Square }\end{array}$} & \multirow{2}{*}{$\begin{array}{l}\text { Std. Error of } \\
\text { the } \\
\text { Estimate }\end{array}$} & \multicolumn{5}{|c|}{ Change Statistics } \\
\hline & & & & & $\begin{array}{l}\text { R Square } \\
\text { Change }\end{array}$ & $\begin{array}{c}\mathrm{F} \\
\text { Change }\end{array}$ & df1 & $\mathrm{df} 2$ & $\begin{array}{c}\text { Sig. F } \\
\text { Change }\end{array}$ \\
\hline 1 & .230 & .053 & -.059 & 43.372 & .053 & .474 & 2 & 17 & .630 \\
\hline
\end{tabular}

a. Predictors: (Constant), Ijarah, Qardh

b. Dependent Variable: Laba Bersih

Sumber : Hasil Penelitian

Berdasarkan tabel diatas dapat diketahui bahwa koefisien determinasi ( $\mathrm{R}$ square) sebesar 0,053 atau 5,3\% artinya pembiayaan ijarah dan pembiayaan qardh secara simultan berpengaruh terhadap laba bersih sebesar 5,3\% sedangkan sisanya dipengaruhi oleh faktor lain.

Tabel 7. Uji F

ANOVA $^{a}$

\begin{tabular}{|ll|r|r|r|r|r|}
\hline Model & Sum of Squares & Df & Mean Square & F & Sig. \\
\hline 1 & Regression & 1784.103 & 2 & 892.051 & .474 & $.630^{\mathrm{b}}$ \\
& Residual & 31979.429 & 17 & 1881.143 & & \\
Total & 33763.532 & 19 & & & \\
\hline
\end{tabular}

a. Dependent Variable: Laba Bersih

b. Predictors: (Constant), Qardh, Ijarah

Sumber : Hasil Penelitian

Berdasarkan tabel diatas dapat diketahui bahwa nilai $\mathrm{F}_{\text {hitung }} 0,474<\mathrm{F}_{\text {tabel }}$ 3,59 dengan nilai sig sebesar 0,630 >0,05 artinya secara simultan pembiayaan ijarah dan pembiayaan qardh tidak berpengaruh signifikan terhadap laba bersih.

\section{KESIMPULAN}

Berdasarkan hasil penelitian maka dapat disimpulkan sebagai berikut :

1. Secara parsial pembiayaan ijarah tidak berpengaruh signifikan terhadap laba bersih.

2. Secara parsial pembiayaan qardh tidak berpengaruh signifikan terhadap laba bersih.

3. Secara simultan pembiayaan ijarah dan pembiayaan qardh tidak berpengaruh signifikan terhadap laba bersih. 


\section{REFERENSI}

Abdillah, W. (2018). Metode Penelitian Terpadu Sistem Informasi Pemodelan Teoritis, Pengukuran, dan Pengujian Statis. Andi.

Akhmad, M. (2016). Hukum Perbankan Syariah. PT. RAJAGRAFINDO PERSADA.

Fatoni, A. (2006). Metodologi Penelitian \& Teknik Penyusunan Skripsi. PT Rineka Cipta.

Husaeni, U. A. (2016). The Variables Effects of Murabahah in Islamic

Commercial Banks. In International Journal of Nusantara Islam (Vol. 04, Issue 02, pp. 1-16).

Husaeni, U. A. (2017). Ekspansi D ETERMINAN P ROFITABILITAS. Ekspansi, 9(1), 155-163.

Husaeni, U. A. and R. J. (2020). Jurnal IUS Kajian Hukum dan Keadilan Fraud Prevention in Islamic Banking. 62(30), 453-471.

Sekaran, U. (2003). Metodologi Penelitian Untuk Bisnis. Salemba 4.

Syafii, A. (2001). bank syariah dari teori ke praktik (Jakarta (ed.)). Gema Insani Press.

Widodo. (2017). Metodologi Penelitian, Populer \& Praktis. PT. RAJA GRAFINDO PERSADA.

Zuhaily, W. (1989). al-fiqh al-islamiy wa adilatuhu, Juz IV. Dar al-Fikr Bairut.

Bank Indonesia. 2007. SE BI No.09/19/PBI/ \{Online\}. Tersedia: https://www.bi.go.id/id/peraturan/perbankan/Pages/pbi_09190 7.aspx $\{17-$ 12-2007\}

Bank BRISyariah. 2017. Laporan Keuangan \{Online $\}$ Tersedia https://www.brisyariah.co.id/tentang hubInvestor.php?f=lapke $\{29 J a n u a r i 201$ 9\} 